MATEUSZ KAMIONKA,

Pedagogical University of Cracow (Kraków, Poland)

e-mail: mattkamionka@gmail.com, ORCID 0000-0002-7316-145X

\title{
INDEPENDENT UKRAINE IN POLISH HISTORICAL SOURCES
}

\begin{abstract}
This year (2021), we are celebrating the 30th anniversary of Ukraine regaining its independence. Poland was the first country to recognise the independence of this Central-Eastern European country in the international arena. In this article, I would like to present and discuss selected journal articles and monographs written by Polish authors as a comment to this critical event. The analysis will be based on selected histographic sources, especially those analysed in terms of ideology, but it will also be reasonable to highlight the most important problems that, according to the authors, the young state may await. Often the fears for the future accompanying the authors of the 90s, unfortunately, proved to be true when we analyse the situation at the beginning of the 21st century. One thing does not change. However, over the first years of bilateral relations, it is difficult to find significant press articles negatively related to this matter, and if there are negative ones, they are mostly marginal.
\end{abstract}

Key word: Ukraine; Independence; Polish perspective; 30 years of independence.

\section{Introduction}

In 2021, we celebrate the 30th anniversary of Ukraine regaining independence. The first internationally recognised country which admitted this step in 1991 was Poland (de facto the first was Lithuania, but it did not exist as an independent state back then). Both in Poland and Ukraine, it often seems that bilateral relations are complicated and strained with historical burdens. Moreover, this is especially true in terms of the conflict connected to the period of WW II. However, it is worth presenting selected opinions of Polish authors who reacted to creating an independent Ukraine in the early 1990s to indicate the "first comments" made about a completely new country, not a part of the USSR which UkrSSR had been. It is difficult to discern some neocolonialism or negative comments in these texts. There were concerns about the further fate of Central and Eastern Europe and the uncertainty related to the collapse of the USSR. The author's central thesis is that "Polish journalists assessed the first years of independent Ukraine as positive bilateral event".

\section{Methods of research}

The research method used in the article was the method of analysing text data. In the course of the research, articles mainly from Gazeta Wyborcza published in the period of independence of Ukraine were selected. In addition, in the second part of the article, selected books were also analysed. The authors discuss the regaining of independence by Ukraine. Most books were somehow connected to the topic of Ukraine or the Polish-Ukrainian relationship. Of course, only selected texts are analysed in the article, which, however, in the author's opinion, are an important voice in the discussion.

Results and Discussion

When writing about any concepts of Polish ideology evaluating the independence of Ukraine, we should go back to the 1950s and the environment of the Paris- émigré monthly journal "Kultura", where its editor-in-chief, Jerzy Giedroyc, together with his associates, created the concept of Poland's eastern policy towards not only Ukraine but the whole Central and Eastern Europe region. This idea, abbreviated as "ULB", was based on several basic demands: Poles as supporters of the antiSoviet policy, national liberation movements and backing state-building aspirations of Lithuanians, Belarusians and Ukrainians; working out political agreement and reconciliation with them over and above the historical disputes and dramatic events; Poles renouncing the restitution of the former eastern areas of the I and the II Republic of Poland, which after the end of World War II became part of soviet, but still - Lithuania, Ukraine and Belarus; and finally, making Poles aware that the raison d'être of their state, resulting from the need to defend against Russian imperialism effectively, is the independence of Poland's eastern neighbours - the Baltic states (primarily Lithuania), Belarus and Ukraine (Waingertner, 2015: 149). One of the great proponents of the idea of "ULB" was Józef Łobodowski - a poet, translator, émigré journalist (he published, among others, in French "Kultura" and "Wiadomości" in London) and a great spokesman for Polish-Ukrainian reconciliation. In 1952, in his article "Against the ghosts of the past", he characterised the first postulates of this idea. It contained the conclusion that Ukraine's independence was/will be in the vital interest of Poland, as was the close political cooperation between Ukraine and Poland. He wrote, "It would be high time for the Poles to understand that the Ukrainians are a separate nation with the same right to independence as any nation. That many negative traits that offend us or hurt us acutely have arisen as a result of the tragic history and the abnormal development of the national culture, constantly constrained by hostile circumstances" (Łobodowski, 1952: 46). This article was so popular that it was reprinted in some polish diaspora journals, like in "Związkowiec" published in Canada, that show that idea 
spread in the elite of the Polish community on both sides of the Atlantic (Opolski, 1952). But it was a small French town Maisons-Laffitte, where "Kultura" was located near Paris, that the idea of Poland's eastern policy, which is still in force today, was created.

It is difficult to say unequivocally that it was only the period of mid-1991 that mobilised Polish non-immigrant intellectuals to create ever bolder opinions about independent Ukraine. Back in 1989, when the first Congress of the National Movement of Ukraine was held in Kyiv, there was a Polish delegation of newly elected MPs from the Solidarity movement (Solidarność), consisted of Zbigniew Janas, Włodzimierz Mokry, Bogdan Borusiewicz, Adam Michnik (Żurawski vel Grajewski, 2016: 68) and Bogumiła Berdychowska heralded a new order. It was soon to arrive not only on the Vistula but also on the Dnieper. During the official celebrations, after his speech, Adam Michnik shouted "Long live a free and democratic Ukraine" to the gathered audience, causing an extended ovation. Even then, precisely two years before the full sovereignty of Ukraine, the fundamental differences between the vision of an independent Ukraine that the Polish opposition had under the aegis of Solidarity and the patriotic milieu of Vyacheslav Chornovil came to light. Although both sides enjoyed joint support of their independence interests concerning the USSR, there were disagreements on historical and social issues. In the book "Testament of Prometheus", Pawel Kowal mentions his conversation with Bogumiła Berdychowska, who participated in the Kyiv convention, which describes an incident that happened at that time. "The Polish delegation was surprised by the coats of arms of Przemyśl and Chelm hung in the meeting room. After the behind-the-scenes intervention, the Ukrainians removed the coats of arms of Polish cities - but the case was used in Soviet propaganda" (Kowal, 2018: 463). It was just a detail, against the backdrop of the backstage discussion related to the "fear" of the Polish delegation about the revival of Ukrainian nationalism, which is why Michnik publicly avoided support for Ukraine's complete independence outside the USSR. However, despite the backstage topics affecting mutual relations in the future, Michnik's speech was interpreted as unequivocal support for Ukrainians at such a difficult time for them. It is also worth quoting an excerpt from the speech of Włodzimierz Mokry, a Polish deputy of Solidarity, who is also a representative of the Ukrainian minority in Poland, who said: "God bless us on the way to freedom of nations in Europe, already with transparent borders between people and nations. Moreover, may God bless us in our further work for the spiritual development of our still enslaved nation, which will be able to sit as a host for the holy supper on our own and free land" (Czech, 1993: 101). Ukraine, however, did not gain sovereignty as a result of the nation's grassroots social initiative but through the prism of Moscow and the entire USSR, which was on the way to collapse. It is difficult not to point out that after the Baltic countries left the USSR, the changes in the Caucasus, and the gradual takeover of the USSR by Russia, Kyiv started to fight for independence. The independence of Ukraine, announced on August 24, 1991, resulted from adapting the ruling nomenclature to the changing political situation. The new state was built not by democratic activists opposing the communists but by representatives of the state apparatus (post-communism). Therefore, independence did not guarantee the Ukrainians' independence from Russia or the democratisation of social and political life (Fedoro- wicz, 2003: 44-45). However, Sebastian Kubas disagrees with this statement. He sees the role of society in regaining sovereignty, "analysing the very process of 1990 and 1991, i.e. Ukraine's transition from the Soviet to independence structures. The main background of these events was the wave of social emotions that accompanied system changes". It is also worth emphasising that the recognition de jure of the independence of Ukraine in Poland has two "founding fathers", some Polish researchers believe that it is mainly due to the rule of Jan Krzysztof Bielecki (Kamiński, Kozakiewicz, 1997: 22). According to the second version, it was Zdzisław Najder from the Chancellery of President Lech Wałęsa who advocated a quick reorientation towards eastern policy. Najder was a critic of the other polish authorities, accusing them of passivity in the eastern policy. He even proposed to recognise the independence of Ukraine without waiting for the results of the referendum that took place in the Eastern Polish neighborhood. First President of Independent Poland - Lech Wałesa, back then still was thinking that, after the collapse of Soviet Union there will be established some Federation of former Republics, not independent states (Boyes, 1995: 330). The contribution of the free Polish press should also be emphasized, which since 1989 reported on the situation in Ukraine, which was still under Moscow's control. Especially in Gazeta Wyborcza, there was often information about events from behind the eastern border or interviews with Ukrainian pro-independence politicians (such as an interview with Pavlo Movchan - Gazeta Wyborcza November 29, 1989).

The beginning of the 90 s was associated with a special surprise related to the collapse of the Soviet Union. It is shown, for example, in a fragment of a book first published in 1992 by Tadeusz Andrzej Olszański entitled "The history of 20th-century Ukraine", in which the author emphasises the emergence of a hazardous phenomenon, that is, the ignorance that an average Pole has about Ukraine, as he wrote "we generally know more about Italy and Spain than about Ukraine" (Olszański, 1994: 294). This knowledge is essential, as he suggests, "Poland must arrange its relations not only with the nation, but also with the Ukrainian state, and the shape of these relations will be of great importance for the future of our country (Poland - author's note)". The author contours his thought referring to the concept of Ukraine as a "buffer" between Poland and an "aggressive empire". At the same time, it was stressed that the Ukrainian-Polish alliance would balance the German-Russian alliance. Also, in the matters of historical memory, Olszański does not overestimate optimism, emphasising both the "rebirth of neoEndet tendencies in Poland" and the Ukrainian "hurra patriotism", concludes that in Ukraine, sympathy and kindness towards Poland prevail, and - as he underlines - it does not seem to be a temporary trend. At the end of his almost three-hundred-page book, Olszański appealed, in a way summarising the keynote of his views on Ukraine's independence, as forgiveness of all wrongs inflicted by his own nation (Olszański, 1994: 296). Władysław A. Serczyk polish historian, as well understood this problem. In the magazine Przekrój, already in october 1991, noted how important it is to show the difficult Polish-Ukrainian history. In his two-page article, he refers to the most important historical events, in a way showing the centuries-old relationship between the neighbors (Serczyk, 1991, 10-11). It is also worth adding that in the subsequent issues of the magazine, Serczyk wrote about: Chmielnicki, Orlik, Mazepa, Doroszenko, 
etc. as part of the series "Heroes of our neighbors". Informing Polish readers about the history of Poland and Ukraine was primarily aimed at initiating a historical dialogue between the neighbors. It was especially important in the context of practically recreating historical bilateral relations. As early as 1991, Adam Michnik, as the editorin-chief of "Gazeta Wyborcza", summed up the decision to create their state by Ukrainians in the article entitled "Koniec Zwiazek Radzicki" (End of the Soviet Union) with the words: "We have waited 45 years for this day. Without faith, without hope, in blind, deaf stubbornness. We lived to see it. Communism is in ruins. The Soviet Union is falling apart on our eyes" (Michnik, 1991: 1). It is worth noting, however, that not all Polish journalists were as optimistic as Michnik, Andrzej Romanowski emphasised in "Tygodnik Powszechny" that it would be difficult for a new state entity to build its sovereignty, inter alia, through strong economic ties between the former components of the USSR.

Moreover, he emphasised that in his opinion, the only solution was to create a confederation of republics. It could prevent conflicts over border revision, which could provide arguments for the rebuilding of a solid central state. He was echoed by Edward Krzemien in the pages of "Wyborcza", who wrote that Ukraine would not be able to exist for a long time without Russia's help, inter alia, due to the weakness of the opposition and the strong position of the post-Soviet nomenclature (Krzemień, 1991: 6). Tadeusz Krząstek focused on the same problem in his book "Ukraine", although he focused on the military issue of Ukraine in 1991-2001. On the other hand, while describing Ukraine's policy, he noted the lack of "its political class and diplomatic corps". The leading politicians gained their education and experience at Soviet universities and in the structures of the authorities of the Ukrainian SSR, and he further summed up, "the new state found itself in a difficult situation. It had to organise the apparatus of power, political life, diplomatic services" (Krzastek, 2002: 89). Sebastian Kubas, who wrote his article in 2001, had a similar opinion: "Ukraine, however, did not have strong nationwide support, and the lack of institutional and intellectual state traditions harmed the young state organism" (Kubas, 2001: 19). Admittedly, Adam Helbowiecz, in his book "Biało-Żowta Ukraina" from 2008, focuses on religious issues in Ukraine. However, he also emphasises the ambiguous relations between the followers of the Roman and Greek Catholic religion during the regaining of independence, "And walk in severe conditions during the Soviet repression, both rites of the same Church provided far-reaching help to each other, and now, surprisingly, in the conditions of unrestricted freedom, close relations have been frozen. A wall of old, historical prejudices of mutual indifference and the lack of openness to each other has grown up" (Helbowicz, 2009: 125).

An essential aspect of the Polish press is defining the Independence of Ukraine as an improvement in Poland's security. In her book written in 2006 entitled "Ukraine between Russia and Poland", Danuta Gibas-Krzak referred to the concept of Ukrainian independence as the primary thesis about improving Poland's security in the face of the threat from Russia (Gibas-Krzak, 2006: 117-118). However, Poles had noticed a visible social division in Ukraine since 1991. In "Gazeta Wyborcza", Leon Bójko reminded us of centuries-old cultural, economic and political ties between Ukraine and Russia. In the inevitable in the journalist's opinion - dispute with Russia, he pointed to the dispute over the territory of Crimea and the so-called Novorossiya (Bójko, 1991: 9). J. Szczerbak agreed, for whom Ukraine was "too divided and Russified" to achieve independence. The activist emphasised that the problems resulting from the division of the nation into the eastern and western parts could be a threat to the implementation of the postulates of the "People's Movement of Ukraine" (Szczerbak, 1990: 7). Tadeusz A. Olszański, as mentioned earlier in his later book, noticed the social division that took place during the period of independence. He believed that the West and the centre of the country were unable to win over the idea of democratisation of the East, where the mass workers' movement was strengthening. The West of Ukraine accused the industrialised East of being "Soviet" and could not come to terms with the Soviet identity of the local not so much Russians as Ukrainians; Donbas, in turn, resented "Bandera nationalism" against the West, not feeling ties and Solidarity with national Ukraine (Olszański, 2003: 35). Michat Klimecki, the author of the updatedadded chapter (written primarily for the 2014 edition) devoted to the history of Ukrainians after 1914 in the book History of Ukraine by Leszek Podhorodecki, only mentioned the tendency for the division of Ukraine into eastern and southern and the Crimea, where he noticed "proRussian separatist tendencies and at the same time antiEuropean moods". He adds that the western and central parts of the country "advocating possibly close ties to its western neighbours, with the European Union and Poland". Thus, summing up that "the challenges facing the Ukrainian state turned out to be greater and far more complicated than it was expected in 1991" (Podhorodecki, 2014).

From Ukraine regaining independence to the Orange Revolution in 2004, as we can see in the above analysis, there have been two main theses that guided Polish journalists and book authors. The first was the fear of the revival of nationalism in the new Ukraine, the nationalism that Poles remember from the period of the Second Polish Republic and the wartime history of Galicia and Volhynia. It is related to the Polish memory of the "Eastern Borderlands-Kresy", and the lack of basic knowledge about the roots of Ukrainian patriotism also developed in other parts of Ukraine, such as in Poltava, Chernihiv or Sumy (and the attitude of these regions to the WestUkrainian version of Ukrainian nationalism). On the one hand, the second theme is the sense of increased security by creating a "buffer" between Poland and Russia. However, it was based initially on the fear of a border war between the new-old Republics immediately after the collapse of the USSR and then on the anticipated conflict between the East and the West of independent Ukraine.

Moreover, the increasing dynamics of Poland's economic development related to the accession to the European Union meant that Ukrainians began to be associated with economic migrants. Joanna Konieczna, the turn of the century, describes this tendency as follows: "Ukraine has been an independent state for over ten years. The Polish-Ukrainian border is nothing like the one from Soviet times. Almost from the beginning of the Polish transformation, Poles have quite intensive contacts with Ukrainians and other citizens of the former USSR countries. These contacts are of a completely different type to those during the communist era, not only because of their unprecedented intensity. Ukrainians often appear in these contacts in a new role, previously unknown to Poles - as economic immigrants involved in trade and 
illegal work (Koniczna, 2003: 2). Thus, after "chasing" Poland to join NATO and the European Union, the issue of economic cooperation with Ukraine was becoming more and more unimportant.

It is worth summarising this article with the words of Jacek Kuron, born in Lviv, one of the leading Polish opposition member, who two years before his death in 2002 in his birth town described his feelings for Ukraine in the following way: "I am absolutely in love with Ukraine, from my early childhood. This incredible, unbelievable will for the independence of Ukrainians, the will to fight for freedom, which is repeated generations after generations, by labour camps, makes me stronger" (Kuroń, 2004: 43). Finally, it should be emphasised that the year 2004 and the events on the "Orange" Majdan practically wholly removed from the Polish scientific and journalistic discourse the topic related to the regaining of independence by Ukraine, and focused on the country's European aspirations and the role of Poland in these aspirations. Essential Polish authors no longer asked what the independence of Ukraine would be, but what Ukraine would be like, whether it would be pro-European or pro-Russian.

\section{Conclusions}

As it is easy to notice, the Polish journalists and authors of books about Ukraine discussed in the text clearly and with hope supported the appearance of a new independent neighbour beyond their eastern border. It must not be forgotten that this was a period when no one could know what would happen next. The Soviet Union was never supposed to collapse, and therefore we often see hopes in the authors' texts and inaccuracy as to the future. However, it is worth emphasising that at the beginning of the 1990s, Polish authors accurately characterised the most significant bilateral challenges and the history of Polish-Ukrainian relations and those related to the internal problems of this mighty country. One thing is sure in the mainstream of considerations on the future of Polish-Ukrainian relations. There was so much of a positive attitude. It is difficult to find an official publication in which the attitude towards the new neighbour would be negative.

\section{REFERENCES}

Boyes, R. (1995). Nagi prezydent: Życie polityczne Lecha Wałęsy, Aneks (In Polish)

Bójko, L. (1991 November 29). Łzy Katarzyny. Gazeta Wyborcza (In Polish).
Czech, M. (Ed.). (1993). Wystąpienie posła W. Mokrego na I zjeździe Ludowego Ruchu Ukrainy, 11 września 1989. Ukraińcy w Polsce 1989-1993. Kalendarium. Dokumenty. Związek Ukraińców w Polsce (In Polish).

Fedorowicz, K. (2003). Transformacja systemowa na Ukrainie etap przejściowy czy nowy model państwa?. Od totalitaryzmu do demokracji. Wybrane problemy okresu przemian (T. Wallas, Ed.) (In Polish).

Gibas-Krzak, D. (2006). Ukraina między Rosją a Polska. Adam Marszałek (In Polish).

Helbowicz, A. (2009). Biło-Żowta Ukrajina. Wołanie z Wołynia (In Polish).

Kamiński, A., Kozakiewicz, J. (1997). Stosunki polsko-ukraińskie. Międzynarodowych Instytutu Spraw Publicznych (In Polish).

Konieczna, J. (2003). Polacy-Ukraińcy, Polska-Ukraina. Paradoksy stosunków sąsiedzkich. Fundacja Stefana Batorego (In Polish).

Kowal, P. (2018). Testament Prometeusza. Kolegium Europy Wschodniej (In Polish).

Krząstek, T. (2002). Ukraina. Vipart (In Polish).

Krzemień, E. (1991, August 26). Ukraina samostijna. Gazeta Wyborcza (In Polish).

Kubas, S. (2001). Ukraińska tożsamość narodowa u progu XXI wieku, Pisma Humanistyczne 3, 5-25 (In Polish).

Kuroń, J. (2004). Wspólna ojczyzna, wspólnych grobów, Zeszyty Literackie, no. 88, Agora (In Polish).

Łobodowski, J. (1952). Przeciw upiorom przeszłości, Kultura, no. 2/52-3/53, 14-66 (In Polish).

Michnik, A. (1991, August 26). Koniec Związku Radzieckiego. Gazeta Wyborcza (In Polish).

Olszański, T.A. (1994). Historia Ukrainy XX w. Volumen (In Polish).

Olszański, T.A. (2003). Trud niepodległości. Ukraina na przełomie tysiącleci. Instytut Studiów Strategicznych Fundacji Międzynarodowe Centrum Rozwoju Demokracji (In Polish).

Opolski, S. (1952, March 16). Przeciw Upiorom Przeszłości. Związkowiec, no.11 (In Polish).

Podhorodecki, L. (2014). Dzieje Ukrainy. Bellona (In Polish).

Romanowski, A. (1991, September 15). Wolność na wschodzie. Tygodnik Powszechny (In Polish).

Ukraina - długa droga do suwerenności (1990, March 30). Tygodnik Solidarność, p. 7 (In Polish).

Serczyk, W. A. (1991, October 13). Jak to między sąsiadami. Przekrój, no. 2416, 10-11. (In Polish).

Waingertner, P. (2015). Jerzego Giedroycia idea ULB - geneza, założenia, próby realizacji. Zarys problematyki. Studia z Historii Społeczno-Gospodarczej, vol. XV, 143-159, http://dx.doi.org/10.18778/2080-8313.15.09 (In Polish).

Żurawski vel Grajewski, P. (2016). Polska polityka wschodnia 1989-2015. Wymiar narodowy i unijny. Ośrodek Myśli Politycznej (In Polish).

Матеуш Камионка,

Краківський педагогічний університет (м. Краків, Польща) e-mail: mattkamionka@gmail.com, ORCID 0000-0002-7316-145X

\section{НЕЗАЛЕЖНА УКРАЇНА В ПОЛЬСЬКИХ ІСТОРИЧНИХ ДЖЕРЕЛАХ}

У 2021 році ми святкуємо 30-ту річницю повернення Україною незалежності. Польща першою визнала незалежність цієї країни Центрально-Східної Європи на міжнародній арені. У статті представлено та про-аналізовано окремі публікації, що ілюструють думки польських авторів, як коментар до цієї важливої події. Аналіз базується на вибраних гістографічних джерелах, особливо тих, що аналізуються 3 точки зору ідеології. Виділено найважливіші проблеми, які, на думку авторів, можуть очікувати на молоду українську державу. На жаль, споглядаючи з висоти 21 століття, ми бачимо, що побоювання авторів 1990-х багато в чому справдилися. Єдине залишається незмінним: протягом останнього покоління важко знайти значущі публікації в пресі, що негативно висвітлюють це питання, а якщо й з'являються негативні, то це - зазвичай маргінальні або інспіровані ззовні дописи.

ключові слова: Україна; незалежність; польська перспектива; 30 років незалежності. 